\title{
Bank Efficiency Analysis: Islamic Banks versus Conventional Banks in the Gulf Cooperation Council Countries 2006 - 2012
}

\author{
Bukhari M. S. Sillah ${ }^{1} \&$ Nizar Harrathi ${ }^{1}$ \\ ${ }^{1}$ Department of Economics, College of Business Administration, King Saud University, Saudi Arabia \\ Correspondence: Bukhari M. S. Sillah, College of Business Administration, King Saud University, P.O. Box 71115, \\ Riyadh 11587, Saudi Arabia. Tel: 966-1146-74-125.
}

Received: May 31, 2015

Accepted: June 15, 2015

Online Published: September 15, 2015

doi:10.5430/ijfr.v6n4p143

URL: http://dx.doi.org/10.5430/ijfr.v6n4p143

\begin{abstract}
This study employs data envelope analysis to produce the efficiency measures for both Islamic and conventional banks and conducts the means tests to investigate the efficiency comparison between the two bank types in the Gulf Cooperation Council (GCC) countries. 28 conventional banks and 20 Islamic banks are selected across the six countries in the GCC according to data availability for the period $2006-2012$. Two output variables, total loans and investments, and four input variables, total deposit, equity, fixed assets and general expenses are used in the DEA. Under the assumption of constant return to scale, no evidence is found for efficiency difference between the two bank types; and under the assumption of variable return to scale, the conventional banks are found to be more efficient than their Islamic counterparts in two points of time, 2009 and 2010, following the 2008 financial crisis. For within country efficiency comparisons, the two bank types are the same in Saudi Arabia, Kuwait and Qatar. The conventional banks are found to be more efficient than their Islamic counterparts in Bahrain and Emirates. The paper finds no evidence for the presence of technological improvements in the banking operations as indicated by the Malmquist productivity analysis.
\end{abstract}

Keywords: banking efficiency, Data Envelopment Analysis, GCC

\section{Introduction}

This paper analyses the efficiency of GCC's banking industry by analyzing the relationship between the outputs and inputs in the industry. In economics, a firm can gain efficiency by increasing the units of output per unit of input, or by holding output constant and reducing input requirements to produce the given output. That's to maximize outputs with given resource, or minimize inputs for producing given outputs. A profit-maximizing firm's right mix of inputs or maximum efficiency is attained at the point where its marginal revenue derived from selling the output is equal to its marginal cost of producing the output. To apply this concept in banking industry, we need to define measures of outputs and inputs problem. There are multiple outputs and inputs, and some inputs at one stage become output at a later stage within the bank. For example, bank deposits are outputs that the bank mobilizes and produce using labor, bank capital and other resources. These mobilized deposits are then inputs together with other resources to produce loans and investments, which in turn are used to generate profits for the bank. One method of analyses that analyzes simultaneously multiple outputs in relation to multiple inputs is data envelope analysis; the current paper relies on this method to accomplish its study. It investigates both the technical and allocative efficiencies of the banks as defined by Farrell (1957). He was the first to provide the derivation of cost efficiency and its division into technical and allocative efficiency. Technical efficiency is the capacity of the decision making unit to maximize output given a certain set of inputs, whereas allocative efficiency is its capacity to sufficiently choose input amount in light of their relative prices. Production or cost functions can be deployed to analyze efficiency. Production function models the maximum output a decision making unit can attain given its mix of inputs; and cost function models the minimum cost that the decision making unit (DMU) can incur in producing a set of outputs. The paper is organized as follows: section 2 discusses the relevant literature; section 3 defines the variables and their measures and presents the methods of analysis, section 4 analyzes the findings, and section 5 derives the conclusions and policy implications.

\section{Some Relevant Literature}

Bank efficiency is often studied on four stages. First, the efficiency is defined and divided into three measures, which are technical, allocative and scale efficiencies. As explained in Wezel (2010), technical efficiency relates to the 
ability of a decision-making unit to maximize the output with given inputs, or minimize input use with a given output level. The allocative efficiency concerns the ability of the decision-making unit to employ in its production the optimal proportion of input mix given their prices in the perfect input market. The scale efficiency relates to the ability of the decision-making unit to function and operate at its optimal size. The second stage of efficiency analysis in the literature concerns the different methods that can be employed to analyze the bank efficiency. There are generally five methods, which are free - distribution approach, thick - frontier approach, data - envelopment approach, OLS method and stochastic frontier analysis. The use of each method is dictated by the type of data available to a researcher and objectives of the researcher. For example, free-distribution method does not set a priori any statistical assumptions about the data. Panel data allows the application of free - distribution method, where fixed and random effects are estimated freely so that if a fixed effect is proven by the data, then bank - specific constant is treated as its inefficiency; and in the case the data approve of a random effect, the average estimated residuals for each bank is considered to be its inefficiency measure, Kamberogoulou et al (2004). Thick-frontier model similarly does not require strict presumptions about distribution of the data, and it is appropriate when the decision-making units have substantial variations in their data. For example, the cost, revenue, labors, and capital values of banks can be of high variations and outliers can disturb the distribution of the data; in this case, thick-frontier approach is the most appropriate method for estimating the efficiency, Berger and Humphrey (1992). Data envelopment analysis is often suitable for the efficiency study when there are multiple outputs and inputs to be investigated simultaneously, and no specific functional form is needed as the data will be treated as an input-output system in a deterministic form, so that any variation not observed in the inputs is considered to be an inefficiency, Berger and Humphrey (1992). Thus, random errors will be wrongly incorporated into the inefficiency scores leading to overestimated measures of inefficiency. This problem is addressed by OLS method stochastic frontier analysis. The OLS method and SFA are parametric, whereas the DEA is non-parametric. The parametric methods hypothesize a functional form and use data to estimate the parameters of that function. The estimated function is then used to derive the estimates of efficiencies of DMUs. The OLS method ignores the randomness effect in the residuals and assumes that the residual term in the regression captures only inefficiency. Because OLS assumes implicitly that residuals have zero mean, the OLS method is corrected or modified to get the true residuals for inefficiency. The OLS method is corrected if its intercept, say a, is adjusted as $a+\max (e i)$, where $\mathrm{e}_{\mathrm{i}}$ is the residual for the $i^{\text {th }}$ firm in the sample. It is modified if its intercept is adjusted as $a+\widehat{E}(U i)$, where $U_{i}$ is the residual of the regression before the modification and $\widehat{E}(U i)=\frac{\sqrt{2}}{\sqrt{\pi}} \sigma_{\mathrm{u}}$ if $\mathrm{U}$ is assumed to follow a half-normal distribution, and $\widehat{E}(U i)=\sigma_{\mathrm{u}}$ if it is assumed to follow an exponential distribution, Mizala et al. (2002). Thanassoulis (2001) finds that OLS method whether corrected or modified can be susceptible to outliers, and it does not allow for random noise, which could lead to biased estimates of efficiency.

The other parametric method of analyzing efficiency is Stochastic Frontier Analysis (SFA). As its name indicates, it does not ignore randomness effect in the residuals. Its residuals are decomposed into the conventional error term and inefficiency term. The conventional error term is an identically and independently distributed two sided error term with zero mean. It captures the random effect, omitted variables, measurement error, etc. The efficiency term is an independently distributed one sided error term with a non-zero mean. Its distribution can be assumed to follow exponential, or half-normal, or truncated normal distribution. The third stage of bank efficiency analysis is set on a comparative study of the banks on the bases of the three measures of efficiency and on the technological change estimated by the Malmquist indices in an attempt to differentiate, for example, domestic banks from foreign banks, state from private banks, small from large banks, Islamic from conventional banks, and banks in one region from others in another region. Drake and Hall (2003) compare the technical efficiencies of banks in Japan, and they find that large banks are less efficient than the small banks. Similar results were found by Bader et al (2008), when they conclude that large banks are more cost, revenue and profit efficient that the small banks. But Koetter (2005) find an 
efficiency edge for small banks over the large banks, and this finding was later confirmed by Berger et al (2009) in Chinese banking sector. Comparing domestic banks with foreign banks, most findings tend to support that foreign banks are more efficient than the domestic banks. Tahir et al (2009) find foreign banks in Malaysia are more efficient than the domestic banks. They find that the inefficiency of domestic banks is attributed to technical inefficiency, whereas the foreign banks are found to suffer from scale inefficiency; both bank types are found to move up the productivity scale. Berger et al (2009) in evaluating the efficiency of Chinese banking industry, they find that foreign banks are the most banking type in China followed by local banks with minority foreign ownerships. In West African banking industry, Kablan (2007) find the local banks to be more efficient than the foreign banks; Wezel (2010) comes to the same conclusions for the Central American Banks versus the foreign banks. In comparing state banks with the private banks, Yudistra (2004) find that publicly listed Islamic banks are efficient that non-listed ones, and Karimzadeh (2012) using a sample of eight Indian banks over the period 2000 - 2010, find public sector banks to be more efficient that private banks. Earlier and similar conclusions were reached by Fu and Heffernan (2007) when they found that publicly listed banks (joint stock banks) in China were more cost efficient that state - owned banks. Contrasting Islamic banks with conventional banks, Yudistra (2004) examine eight banks and find that Islamic banks are slightly more efficient than their conventional counterparts, and that Middle Eastern Islamic banks are less efficient than Islamic banks outside the Middle East. He also finds the small and medium size Islamic banks to suffer from diseconomies of scale, which implies that the Islamic banks need to form mergers to grow and expand their sizes and operations. In a larger sample of 43 Islamic banks and 37 conventional banks over a more recent period from $1990-2005$ across 21 countries, Bader et al (2008) find no evidence for significant efficiency variations between Islamic and conventional banks. This study does suffer from unmatchable input prices as interest expenses are used as prices for the funds when the Islamic banks are supposed not have interest expenses. The principal definition for an Islamic bank is non-interest based financial intermediation. In this comparison analysis, it is shown that publicly listed banks are more efficient than state owned banks. This does appear to prove the economic price theory that private enterprises follow the market price signals for resource mobilization and output production to minimize costs and maximize profits. On the other hand, the state owned banks may not necessarily follow the market price signals to produce their output, instead they respond to policy-stated objectives by the State, which may violate the price efficient signals. No conclusive evidence is found for an efficiency edge for large banks over small banks, and similarly for Islamic banks over conventional banks. The current paper attempts to add some evidence to the debate of efficiency comparison between large and small banks, and between Islamic and conventional banks. On the final stage of bank efficiency analysis, the literature focuses on the relationship between bank efficiency and a number of confounding and contextual factors, such as level of financial development, financial stability, deregulation and reforms, mergers and acquisitions, and risk factors in terms, for example, non-performing loans, operating and financial leverages and other risk variables. Thakor (1998) finds that inefficiency in banking slows down the development of capital markets as inefficient banks attract borrowers from the capital markets, and hence impeding its development. Tabak et al (2011), in investigating the relation between bank efficiency and financial stability in Brazil, find that financial stability is significantly related to bank efficiency. They find changes in bank efficiency to precede loan quality deterioration implying that bank efficiency can function as an early warning indicator of financial instability. Berger and Humphrey (1992) find that highly regulated banking sector suffers from substantial inefficiency; deregulation - such as deregulation of deposits - is found to move up the optimal mix of input use of the banks. Weill (2007) find the efficiency gap between banks in Central and Eastern Europe and banks in Western Europe is significantly explained by differences in the environment and not risk factors. Kablan (2007) conclude that financial soundness, non-performing loans, and banking concentration determine the level of bank efficiency in West African Banking sector. Similarly, Hughes and Mester (2008)'s findings indicate that the environment in which banks operate determine the degree of bank efficiency. Sound property rights, legal and regulatory systems contribute significantly to the bank efficiency. For risk factors, such as bank concentration, financial leverage and non-performing loans, Fiordelisi et al (2010) find that they tend to increase as the bank efficiency deteriorates, and similar findings were earlier confirmed for the Greek banking sector by Kamberoglou et al (2004). Apergis and Alevizopoulou (2011) suggest that without considering risk factors in the efficiency estimation, the inefficiency scores will be overestimated. But there appears to be a bi-directional relation between bank efficiency and risks; fiordelisi et al (2010) find that in European banking sector cost and profit efficiencies are found to granger cause positively bank capital and vice versa. In Turkish banking sector, Eken and Kale (2013) find the profitability of the banks is not matching their risk-taking preferences; and which implies the banks are not profitably efficient given the risk degrees they face.

\section{Data and Methods}

28 conventional banks and 20 Islamic banks are selected for the study across the six countries in the Gulf Cooperation Council. The data are obtained from Bank-scope for the period 2006 to 2012. The two output variables 
represented by bank total loans and other earning assets; and four input variables, total deposit, equity, fixed assets and general expenses are processed in the Data envelope Analysis to produce efficiency measures. Besides, comparative mean tests are conducted for the financial ratio such as return on average asset, returns on average equity to enhance the conclusions reached by the efficiency measures. The data envelope analysis (DEA) does not make any specific assumptions about the distribution of the data, and it can treat a system of multiple inputs and outputs. In a production function, where $\mathrm{Y}$ denotes outputs and $\mathrm{X}$ denotes inputs, DEA assumes that the decision making unit transforms the inputs into outputs in a deterministic form as,

$$
Y_{i}=f\left(X_{i}\right)+\varepsilon_{i}
$$

Where any variation, $\varepsilon$, not observed in the inputs, $\mathrm{X}$, is taken as inefficiency. Thus, the most efficient decision making unit is one that captures all the variations in $\mathrm{X}$ into the outs $\mathrm{Y}$. With multiple outputs and inputs, the transformation process reduces to finding optimal mixes of inputs and outputs for the decision unit. It is obtaining the optimal weights that should be allocated to different inputs and outputs to produce the best rations of outputs to inputs. Specifically, it is to

Maximize $e_{i}=\frac{\sum_{i=1}^{m} u_{i} Y_{i s}}{\sum_{j=1} v_{j} X_{j}} \quad i=1, \ldots ., m . \quad j=1, \ldots ., n$,

Subject to $\frac{\sum_{i=1}^{m} u_{i} Y_{i r}}{\sum_{j=1}^{n} v_{j} X_{j r}} \leq 1 \quad r=1, \ldots \ldots . N$

Where $\mathrm{u}=$ output weights

$\mathrm{v}=$ input weights

The e's represents the technical efficiency measure, which is a weighted input productivity. This measure can be obtained under both constant returns to scale (CRS) and variable returns to scale (VRS). The scale efficiency, which measures the ability of the decision making unit to function and operate at its optimal size, is then obtained by dividing the efficiency under CRS by the efficiency under VRS. To explain the concept of returns to scale, let us derive the average output function from the production function (1) after dropping $\varepsilon$, and we get,

$$
A Y=\frac{Y}{X}=\frac{f(X)}{X}, \mathrm{AY}=\text { average output. }
$$

Returns to scale explains the relationship between the output and the inputs, and by taking the first derivative of the average output function with respect to the input, $\mathrm{X}$, we can understand how the output $\mathrm{Y}$ responds to the changes in $\mathrm{X}$ :

$$
\frac{d A Y}{d X}=\frac{x f^{\prime}(X)-f(X)}{X^{2}}=\frac{f(X)}{X^{2}}\left[\frac{x f^{\prime}(X)}{f(X)}-1\right]
$$

Where $\frac{x f^{\prime}(X)}{f(X)}$ represents the output elasticity to the inputs $\mathrm{X}$, and denoting $\frac{x f^{\prime}(X)}{f(X)}=n$, we get $\frac{d A Y}{d X}=\frac{f(X)}{X^{2}}[n-1]$

If output elasticity is one, meaning the percentage in input will result in the same percentage change in the output, we have a situation of constant returns to scale. This situation also correspond the case where the average output is at its maximum value as its first derivate goes to zero. Any point different from this situation corresponds to variable returns to scale. It could be decreasing returns to scale where the output elasticity is less than one, or increasing returns to scale where the output elasticity is greater than one. 
The efficiency scores obtained under both constant and variable returns to scale are averaged for both Islamic banks and conventional banks. We then conduct the T-test of the null hypothesis that the means of the two samples are equal. To test that the two samples are drawn from different distributions we employ Mann-Whitney (M-W) and Kolmogorov-Smirnov (K-S) statistic tests.

\section{Findings and Analysis}

Table 1 presents the mean efficiency scores for both Islamic and conventional banks for each year. It indicates that both Islamic banks and conventional banks are operating at low efficiency levels under constant returns to scale; they exhibit higher levels of efficiency under variable returns to scale. Overall, the Islamic banks appear to be less efficient than their conventional counterpart under both CRS and VRS.

Table 1. Evolution of DEA efficiency scores (mean values)

\begin{tabular}{ccccccc}
\hline \multirow{2}{*}{ Years } & \multicolumn{2}{c}{ CRS } & \multicolumn{2}{c}{ VRS } & \multicolumn{2}{c}{ SE } \\
& Islamic & Conventional & Islamic & Conventional & Islamic & Conventional \\
\hline 2006 & 0.748 & 0.755 & 0.83 & 0.867 & 0.899 & 0.874 \\
2007 & 0.597 & 0.616 & 0.705 & 0.742 & 0.869 & 0.842 \\
2008 & 0.717 & 0.714 & 0.847 & 0.889 & 0.837 & 0.805 \\
2009 & 0.685 & 0.726 & 0.818 & 0.895 & 0.839 & 0.816 \\
2010 & 0.71 & 0.775 & 0.8 & 0.887 & 0.875 & 0.879 \\
2011 & 0.677 & 0.707 & 0.806 & 0.859 & 0.833 & 0.831 \\
2012 & 0.769 & 0.784 & 0.851 & 0.872 & 0.895 & 0.903 \\
All years & 0.7 & 0.725 & 0.808 & 0.859 & 0.864 & 0.85 \\
\hline
\end{tabular}

Table 2 illustrates the test results of the mean efficiency scores of Islamic banks versus the conventional banks. The table also presents the mean test findings of the some financial ratios of the two bank types to further enhance the mean efficiency tests. Under the constant returns to scale, the Islamic banks are not significantly different from the conventional banks in terms of the technical efficiency. Under the variable returns to scale, the two bank types are found to be different from each other, as the conventional banks emerge more efficient than their Islamic counterparts. However, this difference is persisted only for two years, 2009 and 2010, the two years following the 2008 financial crisis. This could imply that the conventional banks appear to be better able to adjust their operations more quickly and efficiently than the Islamic banks. For the other years under the study $2006-2012$, the two bank types are at par with each other in terms of efficiency.

Table 2. Bank efficiency score and financial ratio analysis

\begin{tabular}{clccccccccc}
\hline Year & \multicolumn{9}{c}{ Efficiency score } & \multicolumn{7}{c}{ Financial ratio } \\
\hline & Test & CRS & VRS & SE & NIM & OOI & NIE & ROA & ROE & CTI \\
All & T test & -1.013 & $-2.349^{* *}$ & 0.798 & $2.5487^{* *}$ & 1.160 & $2.832^{*}$ & $2.445^{* *}$ & -1.259 & $1.704^{* * *}$ \\
Years & M-W & -0.907 & $-2.015^{* *}$ & 0.794 & 1.225 & $2.131^{* *}$ & $4.708^{*}$ & 0.558 & $-2.156^{* *}$ & $3.069^{*}$ \\
& K-S & 0.121 & 0.120 & 0.097 & $0.188^{*}$ & $0.195^{*}$ & $0.286^{*}$ & $0.232^{*}$ & $0.184^{*}$ & $0.219^{*}$ \\
\hline \multirow{2}{*}{2006} & T test & -0.114 & -0.818 & 0.593 & 1.085 & -0.536 & 0.805 & 0.550 & $-1.660^{* * *}$ & 1.336 \\
& M-W & -0.263 & -0.920 & 0.378 & 0.084 & 0.795 & 0.565 & -0.648 & $-1.778^{* * *}$ & $2.238^{* *}$ \\
& K-S & 0.150 & 0.243 & 0.207 & 0.150 & 0.393 & 0.214 & 0.307 & 0.357 & 0.393 \\
\hline \multirow{2}{*}{2007} & T test & 0.091 & -0.225 & 0.689 & 1.549 & -0.552 & 0.790 & 1.095 & -1.620 & 1.410 \\
& M-W & 0.137 & -0.259 & -0.502 & 0.795 & 0.335 & 0.795 & -0.816 & $-1.715^{* * *}$ & 1.485 \\
& K-S & 0.143 & 0.100 & 0.236 & 0.214 & 0.150 & 0.257 & 0.343 & 0.364 & 0.379 \\
\hline \multirow{2}{*}{2008} & T test & -0.323 & -0.943 & 0.199 & 1.501 & 0.646 & 1.254 & 1.254 & 0.325 & 0.769 \\
& M-W & -0.430 & -0.518 & 0.346 & 0.774 & -0.084 & 1.882 & 0.878 & -0.146 & 1.234 \\
& K-S & 0.193 & 0.193 & 0.214 & 0.300 & 0.214 & 0.436 & 0.343 & 0.143 & 0.307 \\
\hline \multirow{2}{*}{2009} & T test & -0.811 & -1.821 & 0.444 & $1.811^{* * *}$ & 1.065 & 1.551 & $1.660^{* * *}$ & -0.027 & 1.294 \\
& M-W & -0.818 & $-1.737^{* * *}$ & 0.766 & 0.983 & 1.589 & 2.551 & 0.439 & -0.230 & 0.920 \\
& K-S & 0.264 & 0.293 & 0.271 & 0.300 & 0.379 & 0.500 & 0.257 & 0.186 & 0.221 \\
\hline \multirow{2}{*}{2010} & T test & -1.053 & $-1.686^{* * *}$ & 0.530 & 0.931 & 1.039 & 1.013 & 2.026 & 0.980 & 0.682
\end{tabular}




\begin{tabular}{clccccccccc} 
& M-W & -0.915 & $-1.704^{* * *}$ & 0.221 & 0.146 & 2.070 & $2.363^{* *}$ & 2.091 & 0.481 & 0.711 \\
& K-S & 0.271 & 0.279 & 0.164 & 0.250 & 0.350 & 0.379 & 0.457 & 0.200 & 0.179 \\
\hline \multirow{2}{*}{2011} & T test & -0.420 & -0.699 & -0.395 & 0.470 & 1.300 & 1.034 & 1.440 & 0.970 & 0.007 \\
& M-W & -0.273 & -0.648 & -0.462 & 0.648 & 1.840 & 2.907 & 1.192 & 0.439 & 0.188 \\
& K-S & 0.229 & 0.179 & 0.164 & 0.293 & 0.350 & 0.486 & 0.264 & 0.164 & 0.164 \\
\hline \multirow{2}{*}{2012} & T test & -0.135 & -0.411 & 0.082 & -1.212 & -0.979 & 1.308 & -1.208 & $-2.619^{* *}$ & 1.434 \\
& M-W & 0.253 & 0.229 & 0.678 & -0.230 & -0.867 & $2.07^{* *}$ & $-2.509^{* *}$ & $-3.534^{*}$ & 1.527 \\
& K-S & 0.271 & 0.193 & 0.186 & 0.214 & 0.261 & 0.371 & 0.436 & 0.586 & 0.336 \\
\hline
\end{tabular}

Notes: *. ** and *** denote rejection of the null hypothesis at $1 \% .5 \%$ and $10 \%$ levels respectively. CRS, VRS and SE denote constant returns to scale, variable returns to scale and scale efficiency respectively. T test is the test of the null hypothesis that the means of the two samples are equal. M-W and KS are the Mann-Whitney and Kolmogorov-Smirnov statistic tests of the null hypothesis that the two samples are drawn from different distributions.

NIM: Net interest margin, OOI: Other operating income, NIE: Non interest expense, ROA: Return on average assets, ROE: Return on average equity, CTI: Costs to income.

In Table 3, we present the tests of mean efficiency scores by country for the overall period $2006-2012$. These tests reveal that only in Bahrain and Emirates that the two bank types are found to diverge significantly from each other. The conventional banks edges more efficiently above their Islamic counterparts in these two countries. These two countries also happen to enjoy strong presence of large international banks in the Gulf Cooperation council. In Saudi Arabia, Kuwait and Qatar, the bank types have no advantage over each other in term of efficiency. No within country mean efficiency tests could be conducted for Oman as it does have Islamic bank designation, and its banks could be categorized into Islamic and conventional banks. We also conduct the test of Malmquist technological change to ascertain any presence of productivity improvement of both bank types over the period of study, no evidence could be found for technological improvement. This implies that the banks in the Gulf Cooperation Council countries have not improved technologically during 2006 -2012. This requires further investigation as by observation, the banking markets of these countries have witnessed entries of new players, whose entry and continuous presence in the market should introduce new ways of doing business different from the status quo.

Table 3. Bank efficiency score and financial ratio analysis: By country

\begin{tabular}{ccccccccccc}
\hline \multicolumn{9}{c}{ Efficiency score } & \multicolumn{7}{c}{ Financial ratio } \\
\hline Country & Test & CRS & VRS & SE & NIM & OOI & NIE & ROA & ROE & CTI \\
\hline \multirow{3}{*}{ Bahrain } & T test & -0.61 & $-5.473^{*}$ & $1.841^{* *}$ & $2.735^{*}$ & -1.350 & -0.33 & $2.505^{* *}$ & 1.239 & -1.094 \\
& M-W & $-1.669^{* * *}$ & $-4.648^{*}$ & 0.281 & 1.384 & 0.498 & 0.993 & $2.246^{* *}$ & 1.329 & $-1.883^{* * *}$ \\
& K-S & $0.281^{* * *}$ & $0.567^{*}$ & 0.225 & 0.216 & 0.178 & $0.338^{* *}$ & $.322^{* *}$ & 0.212 & 0.229 \\
\hline \multirow{2}{*}{ Saudi } & T test & -0.708 & -1.905 & 1.015 & $3.553^{*}$ & $1.694^{* * *}$ & $4.094^{*}$ & $3.092^{*}$ & $-3.071^{*}$ & $2.145^{* *}$ \\
Arabia & M-W & -0.403 & -1.113 & 0.962 & $2.901^{*}$ & 1.166 & $3.835^{*}$ & 1.298 & $-4.214^{*}$ & 1.429 \\
& K-S & 0.261 & 0.3095 & 0.167 & $0.428^{* *}$ & 0.238 & $0.642^{*}$ & $0.452^{*}$ & $0.619^{*}$ & $0.381^{* *}$ \\
\hline \multirow{3}{*}{ Kuwait } & T test & -1.97 & -1.0546 & $-2.124^{* *}$ & 0.381 & 1.564 & $2.148^{* *}$ & 0.7107 & -0.169 & 0.246 \\
& M-W & -1.63 & -0.126 & -1.383 & 0.545 & $2.626^{*}$ & $2^{* *}$ & 0.869 & 0.01 & 0.788 \\
& K-S & 0.345 & 0.2976 & $0.357^{* * *}$ & 0.333 & $0.511^{*}$ & $0.428^{* *}$ & 0.2381 & 0.238 & 0.179 \\
\hline \multirow{3}{*}{ Qatar } & T test & -0.811 & 0.045 & $-1.687^{* * *}$ & $4.975^{*}$ & 0.183 & 0.587 & $3.185^{*}$ & $1.972^{* v}$ & $-3.04^{*}$ \\
& M-W & -0.873 & -0.301 & -1.563 & $3.952^{*}$ & -0.735 & 1.195 & $2.665^{*}$ & $2.481^{* *}$ & $-2.527^{*}$ \\
& K-S & 0.2857 & 0.2143 & 0.286 & $0.857^{*}$ & 0.357 & 0.285 & $0.571^{* *}$ & $0.5^{* * *}$ & $0.714^{*}$ \\
\hline \multirow{2}{*}{ Emirates } & T test & $2.132^{* *}$ & $1.805^{* * *}$ & 1.11 & -1.5857 & $-1.835^{* * *}$ & $2.623^{* *}$ & $-3.520^{*}$ & $-1.869^{* * *}$ & $4.844^{*}$ \\
& M-W & 1.925 & 1.646 & 1.224 & -1.258 & -1.616 & $2.547^{*}$ & $-4.747^{*}$ & $-1.801^{* * *}$ & $6.384^{*}$ \\
& K-S & $0.29^{* * *}$ & 0.2619 & 0.224 & 0.247 & 0.252 & $0.338^{* *}$ & $0.523^{*}$ & $0.323^{* *}$ & $0.752^{*}$ \\
\hline
\end{tabular}

Notes: ${ }^{* * *}$ and ${ }^{* * *}$ denote rejection of the null hypothesis at $1 \% .5 \%$ and $10 \%$ levels, respectively. 


\section{Conclusions and Policy Implications}

Three conclusions can be drawn from this study. First, Islamic banks are not different from the conventional banks in terms of technical efficiency under the assumption of constant returns to scale for the period $2006-2012$. Under the assumption of variable returns to scale, conventional banks appear to be more efficient. Nevertheless, this advantage for the conventional banks is detected only for 2009 and 2010 following the 2008 financial crisis. The implications are that, under perfect competition which also means constant returns to scale, the two bank types are the same in efficiency measures and their efficiency measures are substantially lower than that under variable returns to scale. The Islamic banks are less efficient compared to their conventional counterparts to adjust their operations in the aftermath of the 2008 financial crisis. Second, the within country mean efficiency tests indicate that conventional banks are more efficient than their Islamic counterparts only in two countries, namely Bahrain and Emirates. The implications from this conclusion is that because these two countries have strong presence of large international banks, which are conventional banks, the results are biased towards these international conventional banks, whose experience and large international operations will make edge competitively efficiently above their local counterparts including the Islamic banks, who are all local in nature. In the absence of strong presence of large international banks, in the case of Saudi Arabia, Kuwait and Qatar, the local conventional banks are no different from the local Islamic banks. Finally, the study finds no evidence of technological improvement in the banking operations in the Gulf Cooperation Council countries as indicated by the tests of Malmquist productivity analysis. Two f questions beyond this current study need further investigation. More insights can be obtained by categorizing the banks into local, Islamic, mixed and international owned banks to dissect what specific bank type does enjoy efficiency edge; and whether the entry of international banks have any technological improvements for the banking markets.

\section{Acknowledgements}

The authors would like to thank the Deanship of Scientific Research at the King Saud University represented by the research center at CBA for supporting this research financially.

\section{References}

Abd Karim, Mohd Zainin, Chan, Sok-Gee, \& Hassan, Sallahudin. (2010). Bank efficiency and non-performing loans: evidence from Malaysia and Singapore. Prague Economic Papers, 2.

Abdulai, A., \& Tietje, H. Estimating technical efficiency under unobservable heterogeneity with stochastic frontier models: application to Northern German dairy farms. European Review of Agricultural Economics, 1-24.

Alexander, W., Robert, J., Hang, A. A., \& Jaforullah, M. (2007). A two stage double bootstrap data envelopment analysis of efficiency differences of New Zealand secondary schools. University of Otago, Economics Discussion papers No. 0714.

Apergis, N., \& Alevizopoulou, E. (2011). Bank efficiency: evidence from a panel of European banks. Panoeconomicus, 3, 329-341.

Attaullah, A., Cockerill, T., \& Le, H. (2004). Financial liberalization and bank efficiency: a comparative analysis of India and Pakistan. Applied Economics, 36(17).

Bader, Mohammed Khaled I., Mohamad, Shamsher, Ariff, Mohamed, \& Hassan, Taufiq. (2008). Cost, revenue, and profit efficiency of Islamic versus conventional banks: International evidence using data envelopment analysis. Islamic Economic Studies, 15(2), 24-76.

Berger, A, N., \& Humphrey, D. B. (1992). Measurement and efficiency issues in commercial banking. A chapter in the volume of Output Measurement in the Service Sectors, National Bureau of Economic Research, University of Chicago Press, Retrieved from http://www.nber.org/chapters/c7237

Berger, A. N., Hasan, I., \& Zhou, M. (2009). Bank ownership and efficiency in China: What will happen in the world's largest nation?. Journal of Banking and Finance, 33, 113-130.

Callahan, R. (1962). The Cult of Efficiency. Chicago, University of Chicago, University of Chicago Press.

Charnes, A., Cooper, W. W., \& Rhoades, E. (1978). Measuring the efficiency of decision making units. European Journal of operational Research, 6, 429-444.

Drake, L., \& Maximilian, J. B. H. (2003). Efficiency in Japanese banking: An empirical analysis. Journal of Banking and Finance, 27, 891-917.

Eken, M. H., \& Kale, S. (2013). Evaluating the efficiency of Turkish banks: a risk and profitability approach. The Business and Economics Research Journal, 6(1), 53-68. 
Farell, M. J. (1957). The measurement of productive efficiency. Journal of the Royal Statistical Society, 120, Part III, Series A, 253-281.

Fiordelisi, F., Marques-Ibanez, D., \& Molyneux, P. (2010, June). Efficiency and risk in European banking. European Central Bank Working Paper Series No.1211, June 2010.

$\mathrm{Fu}, \mathrm{X}$., \& Heffernan. (2007). Cost efficiency in China's banking sector. China Economic Review, 18, 35-53.

Fäe, R., Kirkley, J. E., \& walden, J. B. (2007). Estimating capacity and efficiency in fisheries with undesirable outputs. Virginia Institute of Marine Sciences, VIMS Marine Resource Report August No.2007- 6.

Grandderson, G., \& Linville, C. (2002). Regulating efficiency and Granger causality. International Journal of Industrial Organization, 20, 1225-1245.

Herrero, I., \& Pascoe, S. (2002). Estimation of technical efficiency: a review of some of the stochastic frontier and DEA software. Computers in Higher Education: Economics Review, 15(1).

Hughes, J., \& Mester, L. J. (2008). Efficiency in banking: Theory, practice and evidence. Federal Reserve Bank of Philadelphia, Research Department Working paper No. 08-1.

Kablan, S. (2007). Measuring bank efficiency in developing countries: the Case of WAEMU (West African Economic Monetary Union). African Research Consortium, May 2007.

Kamau, A. W. (2011). Intermediation efficiency and productivity of the banking sector in Kenya. Interdisciplinary Journal in Business, 1(9), 12-26.

Kamberoglou, N. C., Liapis, E., Simigiannis, G. T., \& Tzamourani, P. (2004). Cost efficiency in Greek banks. Bank of Greece Working paper No.9.

Karimzadeh, M. (2012). Efficiency analysis by using Data envelope analysis model: evidence from Indian banks. International Journal of Latest Trends in Finance and Economic Science, 2(3), 228-237.

Koetter, M. (2005). Measurement matters - input price proxies and bank efficiency in Germany. Deutsche Bundesbank, Discussion Paper series 2: banking and Financial Studies No. 01/2005.

McMahon, W., \& Geske, T.G. (eds.). In Financial Education: Overcoming inefficiency and Inequity, pp. 52-77. Urban, IL: University of Illinois Press.

Mizala, A., Romaguera, P., \& Farren, D. (2002). The technical efficiency of schools in Chile. Applied Economics, 34(12), 1533-1552.

Shao, B. B. M., \& Lin, W. T. (2002). Measuring the value of information technology in technical efficiency with stochastic production frontier. Information and Software technology, 43, 447-456.

Tabak, B. M., Craveiro, G. L., \& Cajueiro, D. O. (2011). Bank efficiency and efault in Brazil: causality tests. Banco Central Do Brasil, Working paper series 255.

Tahir, Izah Mohd, Abu Bakar, Nor Mazlina, \& Haron, S. (2009). Evaluating efficiency of Malaysian banks using DEA. International Journal of Business and Management, 4(8), 96-106.

Thakor, A. V. (1998). Bank efficiency and financial system evolution: an analysis of complementary problems in transitional and state-dominated economies. Research Economics, 52, 271-284.

Thanasoulis, E. (2001). Introduction to the Theory and Application of Data Envelopment Analysis: A Foundation Text with Integrated Software. Kluwer Academic Publishers, Boston.

Weill, L. (2007). Is there a gap in bank efficiency between CEE and Western European Countries?. Comparative Economic Studies, 49, 101-127.

Wezel, T. (2010). Bank efficiency amid foreign entry: evidence from Central American Region. International Monetary fund, Working paper WP/10/95.

Yudistra, D. (2004). Efficiency in Islamic banking: an empirical analysis of eighteen banks. Islamic Economic Studies, 12(1), 1-19. 